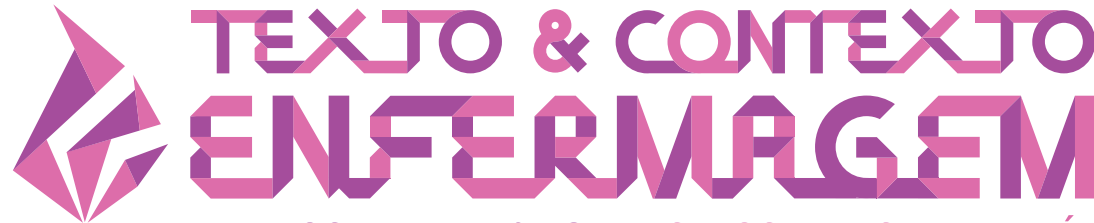

TEXT \& CONTEXT NURSING TEXTO \& CONTEXTO ENFERMERÍA

\section{IMPACT OF PLAN-DO-STUDY-ACT CYCLES ON THE REDUCTION OF ERRORS RELATED TO VACCINE ADMINISTRATION}

\author{
Monica Batista Mendes Nunes ${ }^{1}$ (D) \\ Thalyta Cardoso Alux Teixeira ${ }^{1}$ (i) \\ Carmen Silvia Gabriel ${ }^{1}$ (D) \\ Fernanda Raphael Escobar Gimenes ${ }^{1}$ (i)
}

\footnotetext{
${ }^{1}$ Universidade de São Paulo, Escola de Enfermagem de Ribeirão Preto, Programa de Pós-Graduação Mestrado
} Profissional em Tecnologia e Inovação em Enfermagem. Ribeirão Preto, São Paulo, Brasil.

\begin{abstract}
Objective: to evaluate the impact of a quality improvement program in the reduction of errors related to vaccine administration.

Method: an intervention study aimed at comparing outcome measures before (Phase I) and after (Phase II) the implementation of a quality improvement program. It was carried out in a Basic Health Unit in the inland of São Paulo from March 2019 to November 2019. In the first phase, there was direct observation by Nursing professionals during the preparation and administration of the doses. In the second phase, an error was selected and subjected to four Plan-Do-Study-Act cycles to test the changes. The following quality tools were also used: root cause analysis, Ishikawa diagram and Pareto diagram.

Results: a total of 164 doses of vaccines prepared and administered to 51 users were observed; 527 errors were identified and categorized into 13 types. In $27.7 \%$ of the observations made in Phase I, the users/ guardians were not informed about potential adverse reactions. The goal of $100 \%$ of guidelines was established over an eight-month period, which was achieved in the second Plan-Do-Study-Act cycle and maintained in the third and fourth cycles, with confirmed improvement in the process.

Conclusion: the quality improvement approach, based on Plan-Do-Study-Act cycles, contributed to the reduction of errors in the administration of vaccines and the change was sustainable, as it maintained over time.
\end{abstract}

DESCRIPTORS: Vaccines. Drug-related side effects and adverse reactions. Quality assurance of health care. Patient safety. 


\section{IMPACTO DE CICLOS PLAN-DO-STUDY-ACT NA REDUÇÃO DE ERRO RELACIONADO À ADMINISTRAÇÃO DE VACINA}

\section{RESUMO}

Objetivo: avaliar o impacto de um programa de melhoria da qualidade na redução de erros relacionados à administração de vacina.

Método: estudo de intervenção, voltado para a comparação de medidas de resultados antes (Fase I) e após (Fase II) a implementação de um programa de melhoria da qualidade. Foi realizado em uma Unidade Básica de Saúde do interior paulista no período de março a novembro de 2019. Na primeira fase, ocorreu observação direta dos profissionais de enfermagem durante o preparo e a administração das doses. Na segunda fase, um erro foi selecionado e submetido a quatro ciclos Plan-Do-Study-Act para testar as mudanças. Também foram utilizadas as ferramentas da qualidade: análise de causa raiz, diagrama de Ishikawa e diagrama de Pareto. Resultados: foram observadas 164 doses de vacinas preparadas e administradas em 51 usuários; 527 erros foram identificados e categorizados em 13 tipos. Em 27,7\% das observações realizadas na Fase I, os usuários/responsáveis não foram orientados sobre potenciais reações adversas. Foi estabelecida a meta de $100 \%$ de orientações em um período de oito meses, a qual foi atingida no segundo ciclo Plan-Do-Study-Act e mantida no terceiro e quarto ciclos, sendo confirmada a melhoria no processo.

Conclusão: a abordagem de melhoria da qualidade, baseada em ciclos Plan-Do-Study-Act, contribuiu com a redução de erro na administração de vacinas e a mudança foi sustentável, pois se manteve ao longo do tempo.

DESCRITORES: Vacinas. Efeitos colaterais e reações adversas relacionados a medicamentos. Atenção primária à saúde. Garantia da qualidade dos cuidados de saúde. Segurança do paciente.

\section{IMPACTO DE LOS CICLOS PLAN-DO-STUDY ACT EN LA REDUCCIÓN DE ERRORES RELACIONADOS CON LA ADMINISTRACIÓN DE VACUNAS}

\section{RESUMEN}

Objetivo: evaluar el impacto de un programa de mejora de la calidad en la reducción de errores relacionados con la administración de vacunas.

Método: estudio de intervención, dirigido a comparar medidas de resultado antes (Fase I) y después (Fase II) de la implementación de un programa de mejora de calidad. Se llevó a cabo en una Unidad Básica de Salud del interior de São Paulo de marzo a novembro de 2019. En la primera fase, hubo observación directa por parte de profesionales de enfermería durante la preparación y administración de dosis. En la segunda fase, se seleccionó un error que fue sometido a cuatro ciclos Plan-Do-Study-Act para comprobar los cambios. Además, se utilizaron herramientas de calidad: análisis de causa raíz, diagrama de Ishikawa y diagrama de Pareto.

Resultados: se observaron 164 dosis de vacunas preparadas y administradas a 51 usuarios; Se identificaron 527 errores y se categorizaron en 13 tipos. En el 27,7\% de las observaciones realizadas en la Fase I, los usuarios / tutores no fueron informados sobre posibles reacciones adversas. La meta del $100 \%$ de los lineamientos se estableció en un período de ocho meses, la cual se logró en el segundo ciclo Plan-Do-StudyAct y se mantuvo en el tercer y cuarto ciclos, confirmándose la mejora en el proceso.

Conclusión: el enfoque de mejora de la calidad, basado en ciclos Plan-Do-Study-Act, contribuyó a la reducción de errores en la administración de vacunas y el cambio se consideró sostenible, dado que se mantuvo en el tiempo.

DESCRIPTORES: Vacunas. colaterales y reacciones adversas relacionados con medicamentos. Primeros auxilios. Aseguramiento de la calidad de la atención médica. Seguridad del paciente. 


\section{INTRODUCTION}

Medication errors are among the main causes of adverse events in the health systems and affect approximately 1.3 million people 1 . It is estimated that $5 \%$ to $6 \%$ of the hospitalizations are caused by medication errors and that low- and middle-income countries are disproportionately impacted ${ }^{2}$.

Medication errors can occur at any stage of the medication use process; however, administration errors are one of the most common and the most difficult to intercept ${ }^{1}$.

The causes of administration errors are multifactorial and, in general, are related to poorly planned systems. A recent systematic literature review revealed that the main causes of errors in administration were related to unsafe actions, lack of knowledge, and deliberate violations by the health professionals ${ }^{1}$.

It is noteworthy that most of this data comes from research studies conducted in hospitals but, according to the Organization for Economic Cooperation and Development (OECD), nearly half of the global burden of adverse events originates in Primary Health Care (PHC) and the most common events involve the use of medications. In addition, medication errors in PHC result in moderate or severe harms ${ }^{3}$ and represent up to $20 \%$ of all hospital admissions ${ }^{4}$.

According to a report of notifications from European os suspected adverse drug reaction reports (EudraVigilance), a European pharmacovigilance database, from 2001 to 2016 most of the medication errors were related to the administration of vaccines and resulted in mild harms ${ }^{5}$.

Vaccine-related medication errors are defined by any preventable event that may favor inappropriate use or cause harms to the user. Such events can be related to the professional practice, immunization products (vials, needles, syringes), storage, distribution and administration ${ }^{6}$.

A research study conducted based on data from the online Post-Vaccination Adverse Event Surveillance Information System (SI-EAPV) also showed cases of adverse events involving the administration of vaccines in the Brazilian scenario. According to the researchers, the highest incidence coefficient of adverse event after vaccination, per 100,000 inhabitants, was among children under 4 years old and the systemic neurological clinical manifestations were the most frequent, corresponding to $59.5 \%$ of the signs and symptoms ${ }^{7}$.

These results mostly show human failures, which can occur due to lack of attention, knowledge or experience of the professional working in the vaccine room, and it is up to the leaders to identify the problems existing in the processes, as well as the necessary changes to improve the health results of users who need to be vaccinated.

In this sense, the science of quality improvement can be used in order to improve safety in the administration of vaccines, in Primary Health Care (PHC). Methods focused on quality improvement can incorporate a wide range of methodologies, in addition to considering the context and social complexity ${ }^{8}$.

In this study, the methodology proposed by the Institute for Healthcare Improvement $(\mathrm{IHI})^{8}$ was selected for being widely used in countries such as the United Kingdom ${ }^{9}$, Australia ${ }^{10}$, and the United States of America (USA) ${ }^{11}$ to improve the quality of care and safety provided to the patient, although little explored in Brazilian research studies. It is a simple but powerful tool that speeds up the quality improvement process ${ }^{12}$.

The science of improvement emphasizes innovation through rapid tests carried out in real work environments, as well as propagation of the results, in order to generate learning about the changes that resulted in improvements ${ }^{13}$. The methodology involves answering three fundamental questions combined with Plan-Do-Study-Act (PDSA) cycles to form the basis of the continuous improvement model (Figure 1). 


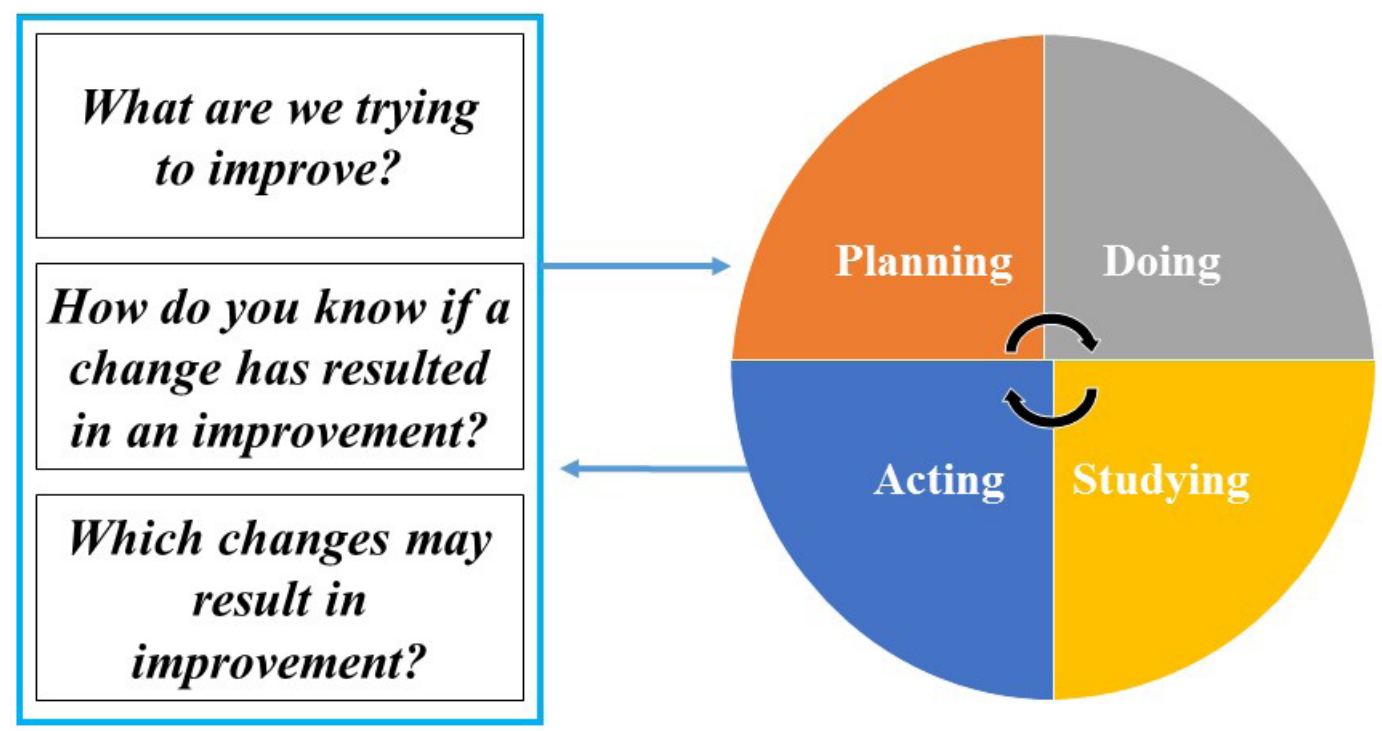

Figure 1 - Quality improvement methodology.

Source: Adapted from Institute for Healthcare Improvement ${ }^{7}$

According to the National Health Surveillance Agency (ANVISA) ${ }^{14}$, the IHI methodology consists of a scientific method used for action-oriented learning that provides a detailed study of the changes to be implemented. Therefore, the methodology optimizes quality improvement and is recommended for use in the health services.

The lack of previous research studies in the Brazilian context represents a challenge but, at the same time, it highlights the importance of this study in improving the safety of users using vaccines. Therefore, this study aimed to assess the impact of a quality improvement program in the reduction of errors related to vaccine administration.

\section{METHOD}

From March 2019 to November 2019, an intervention study was carried out to compare results measures before (Phase I) and after (Phase II) the implementation of a quality improvement program. For the description of the different stages of this study, the SQUIRE (Standards for Quality Improvement Reporting Excellence) guidelines were used ${ }^{15}$.

A Basic Health Unit (BHU) in the inland of São Paulo was chosen for the study, located in Araraquara, which serves an estimated population of 15,000 inhabitants.

A total of 164 doses of vaccines were observed in the eight-month study period, prepared by 12 Nursing professionals and administered to 51 users.

An electronic data collection form developed by the researcher on the Survey Monkey ${ }^{\circledR}$ online platform was used. This form was validated in terms of face and content by a panel made up of five specialists. Data collection was carried out in two phases, using a mobile device.

The interventions (or changes) tested were the following: training of the Nursing team on the theme of "Adverse reactions to vaccines", training of the Nursing team on approaching the user and/ or responsible person on the theme of "Adverse reactions to vaccines"; elaboration and availability, in the vaccination room, of a detailed folder containing the types of vaccines and their local and systemic reactions for consultation by the Nursing team; elaboration and availability, in the vaccination room, of a folder banning the use of cell phones to users and/or guardians. 
The study was developed in two phases. The first, called baseline, was used to diagnose the problem, that is, it was carried out with the objective of identifying the frequencies and types of errors related to the preparation and administration of vaccines, selecting a type of error and identifying the probable causes.

During a month, direct observation of the Nursing professionals was performed at the time of the user's reception in the vaccination room and during preparation and administration of the doses. Direct and participant observation of the vaccine preparation and administration processes was carried out by the researcher and by a trained nurse not linked to the BHU, using a guide developed by the researcher. The guide was based on the guidelines contained in the Vaccine Manual of the Ministry of Health ${ }^{16}$.

Subsequently, the results were presented to the BHU team and a type of error was selected for the root cause analysis to apply the PDSA cycle. At this point, the quality improvement team was established and the professionals who accepted to participate voluntarily were asked to sign the Free and Informed Consent Form (FICF). The team consisted of 13 nursing technicians, 2 nurses, a general practitioner and a pediatrician.

The team was invited to categorize the causes of the error individually, according to the London Protocol categories ${ }^{17}$, namely: patient, task, individual, team, work environment and organizational management. After each team member categorized the causes, the researcher analyzed and compiled the results in the Ishikawa (or fishbone) diagram. Additionally, the researcher prepared a graphic representation of the main causes of the error to prioritize the strategies for change. Subsequently, the team started planning improvement actions with the help of the IHI PDSA Form ${ }^{18}$.

In phase 2, the goal of the quality improvement program was established: to increase to $100 \%$ the guidelines given to the users and/or companions on potential adverse events related to the administration of vaccines, over an eight-month period. Nine meetings were held with the quality improvement team over a six-month period, lasting up to 120 minutes each, in order to discuss which changes could be tested to increase the percentage of guidelines provided by the Nursing team to the users/guardians.

It took four consecutive PDSA cycles, carried out from August to November 2019, to reach the goal. A total of 104 doses of vaccines were observed, prepared by 12 Nursing professionals and administered to 51 users.

The following changes were gradually implemented by the quality improvement team over a three-month period (after three months from the baseline):

Cycle 1: the Nursing team was trained on potential adverse reactions related to vaccines.

Cycle 2: the Nursing team was trained on how to approach the user and/or guardian about adverse events related to vaccines, and a detailed folder containing the types of vaccines and local and systemic reactions was made available in the vaccination room for consultation by the Nursing team.

Cycle 3: a folder banning the use of cell phones by users and/or guardians was created and posted in the vaccination room during the administration of vaccines.

Cycle 4: this cycle was designed to assess whether the change resulted in improvements and whether they have continued over time.

The results of each cycle were presented at meetings with the Nursing team and feedback was obtained to decide the next steps. Finally, the percentages of guidelines on potential vaccine-related adverse reactions were measured before and after the quality improvement program.

The data from the Survey Monkey® platform was transferred to Excel spreadsheets. For data analysis, the following quality tools were used: root cause analysis, to explore the causes of the errors that occurred during preparation and administration of the vaccine doses; Ishikawa diagram, to draw the causal factors of the errors; Pareto diagram, to identify the factors that deserved more 
attention from the team and that would need to be the focus of improvement actions; trend graph, to graphically demonstrate whether the changes tested resulted in improvements and whether they have continued over time. The results were also presented by means of absolute and relative frequencies made available in tables and graphs.

The percentage of guidelines given to the users and/or guardians was calculated by dividing the total observed doses by the total observed errors (that is, failures to guide users and/or guardians), multiplied by 100 .

All the participants who voluntarily accepted to participate in the study signed the FICF in two copies. The study was approved by the Research Ethics Committee of Escola de Enfermagem de Ribeirão Preto at Universidade de São Paulo.

\section{RESULTS}

The Nursing professionals who participated in the study were all female (8; 100\%), aged between 30 and 65 years old (mean of 41.37 years old), nursing technicians, with experience in the area between six and 35 years (mean of 19.2 years) and working in the vaccination room between six months and 26 years (mean of 6.89 years).

Among the BHU users included in the study, the majority were female $(34 ; 56.7 \%)$, with ages ranging from two months to 69 years old.

In Phase I of the study (baseline), the preparation and administration of 60 doses of vaccines were observed. A total of 527 errors were found, classified in 13 categories; and the most frequent were related to the techniques: The preparation was not carried out in a clean and dry place (57; 95\%); Did not perform pain reduction technique (55; 91.7\%); Did not observe the occurrence of adverse events (55; 91.7\%); Did not use the $Z$ technique for intramuscular administration (48; 80\%) (Table 1).

Table 1 - Distribution of the frequencies and types of errors in the preparation and administration of vaccines. Araraquara, SP, Brazil, 2019. $(n=60)$

\begin{tabular}{|c|c|c|}
\hline \multirow{2}{*}{ Types of errors } & \multicolumn{2}{|c|}{ Frequency } \\
\hline & $\mathbf{n}$ & $\%$ \\
\hline \multicolumn{3}{|l|}{ Welcoming } \\
\hline Did not check past health history & 41 & 68.3 \\
\hline \multicolumn{3}{|l|}{ Dose preparation } \\
\hline Did not prepare the dose in a clean and dry place & 57 & 95 \\
\hline Did not clean the vial with clean and dry cotton & 45 & 75 \\
\hline Contaminated the vaccine vial during preparation & 44 & 73.3 \\
\hline Did not verify the integrity of the packaging & 37 & 61.7 \\
\hline Did not clean hands before preparation & 11 & 18.3 \\
\hline \multicolumn{3}{|l|}{ Vaccine administration } \\
\hline Did not perform pain reduction technique & 55 & 91.7 \\
\hline Did not use the $Z$ technique for intramuscular administration & 48 & 80 \\
\hline Did not clean hands before administration & 44 & 73.3 \\
\hline Did not clean the administration site with dry cotton & 29 & 48.3 \\
\hline \multicolumn{3}{|l|}{ Post-vaccination procedures } \\
\hline Did not observe the occurrence of adverse events & 55 & 91.7 \\
\hline Did not advise on the expected adverse reactions & 31 & 51.7 \\
\hline Did not wash hands after applying the vaccine & 30 & 50 \\
\hline
\end{tabular}


After identifying the frequencies and types of errors in the preparation and administration of vaccines, the results were presented to the root cause analysis team that chose the focus of the improvement actions: Lack of guidance to the users and/or guardians about potential vaccine-related adverse events. Figure 2 shows the cause and effect diagram.

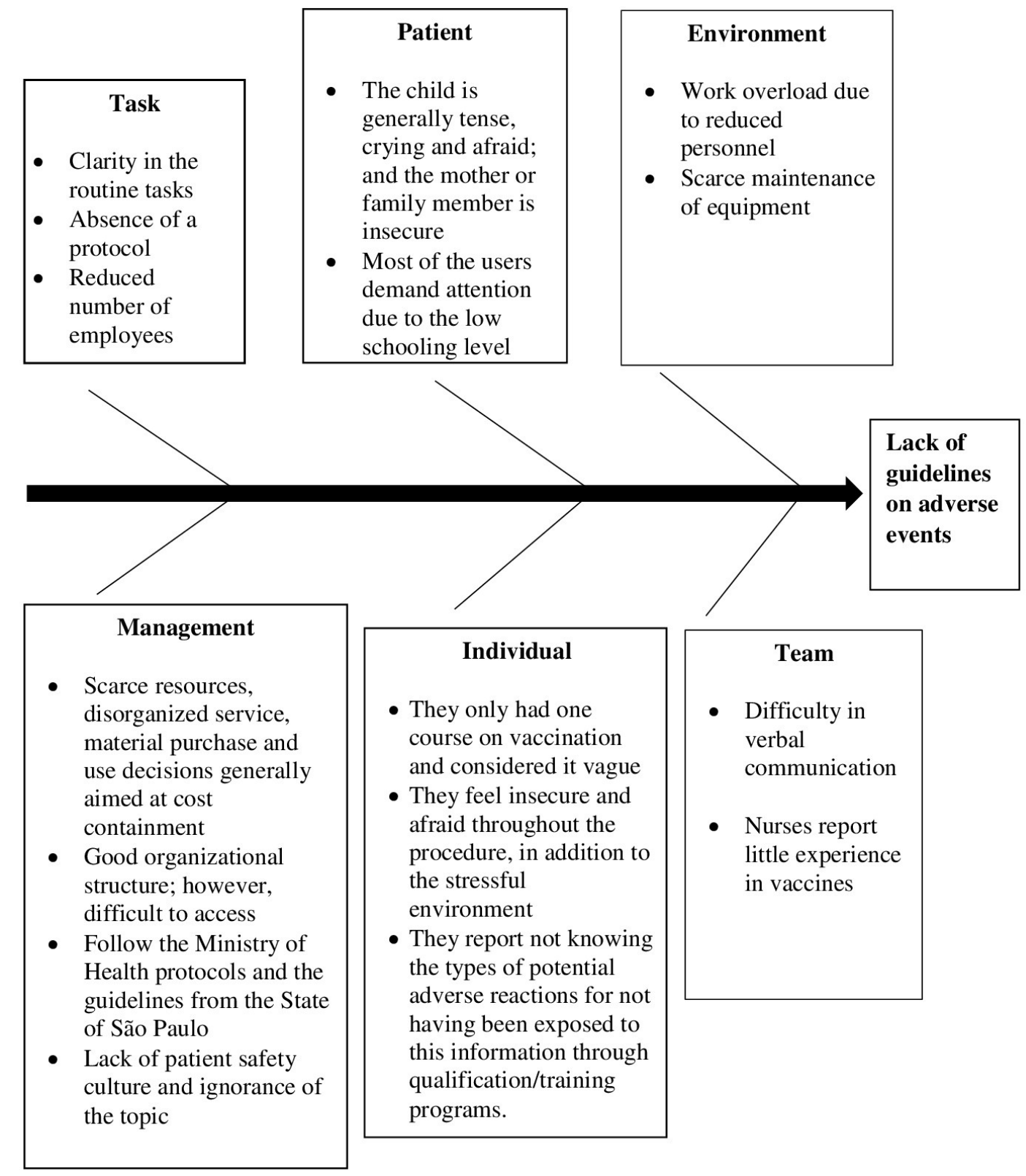

Figure 2 - Cause and effect diagram on the causal factors of the lack of guidance on vaccine-related adverse events. Araraquara, SP, Brazil, 2019.

Subsequently, the Pareto diagram was designed to identify the factors that deserved more attention from the team and that exerted more influence on the lack of guidance to the users about potential adverse reactions to vaccines. Figure 3 shows that approximately $80 \%$ of the causes that interfere in the lack of guidance to the users and/or guardians about potential adverse reactions to vaccines are related to the Environment $(37 ; 26.8 \%)$, Management $(32 ; 23.2 \%)$, Patient $(22 ; 15.9 \%)$ and Team $(21 ; 15.2 \%)$.

Subsequently, PDSA cycles were planned and carried out in order to achieve the goal established for the quality improvement project. 


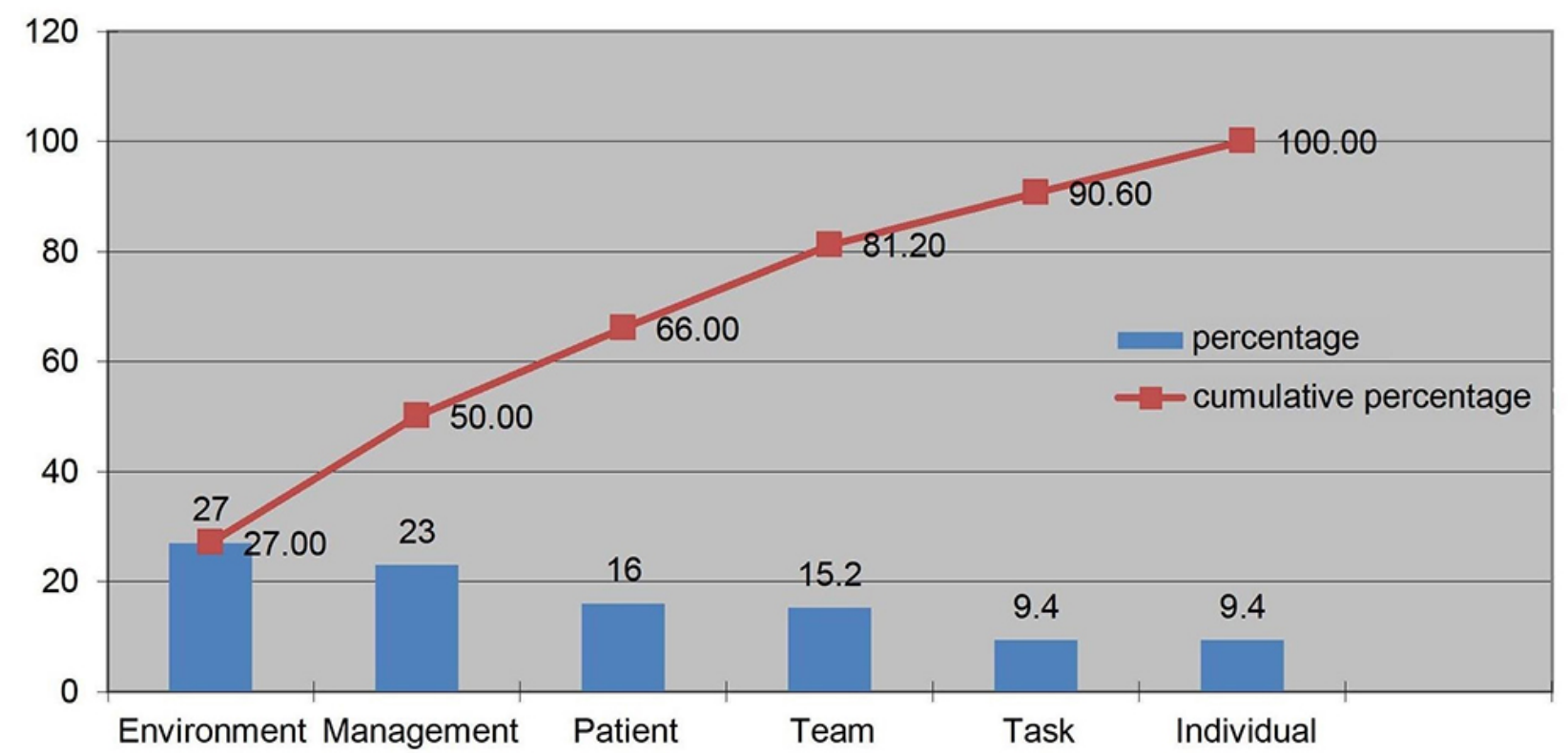

Figure 3 - Pareto diagram of the causes that interfere in the lack of guidance to the users and/or guardians about potential adverse reactions to vaccines. Araraquara, SP, Brazil, 2019.

\section{$1^{\text {st PDSA Cycle }}$}

Three nursing technicians were observed during the preparation and administration of 18 doses of vaccines. In $13(72.2 \%)$, the users/guardians were informed about possible adverse reactions, while five $(27.8 \%)$ did not receive such guidelines. There was an increase in the percentage of guidelines from $48.3 \%$ to $72.2 \%$, after five months of Phase I. However, the goal of $100 \%$ of guidelines foreseen for the improvement project was not achieved.

\section{$2^{\text {nd }}$ PDSA Cycle}

Three nursing technicians were observed during the preparation and administration of 30 doses of vaccines and $100 \%$ of the users and/or guardians were advised about possible adverse reactions. An increase in the percentage of guidelines was observed from $48.3 \%$ to $100 \%$, after four months of Phase I. Therefore, the goal of $100 \%$ of guidelines foreseen for the improvement project was reached in the second cycle.

\section{$3^{\text {rd }}$ PDSA Cycle}

Twelve days after the second PDSA cycle, three nursing technicians were observed during the preparation and administration of 21 doses of vaccines. Again, $100 \%$ of the users and/or guardians were informed about potential adverse reactions. Therefore, the goal foreseen for the improvement project was maintained after the second PDSA cycle.

\section{$4^{\text {th }}$ PDSA Cycle}

Thirty days after the third cycle, 13 nursing technicians were observed during the preparation and administration of 34 doses of vaccines. Figure 4 shows that there was an increase in the percentage of guidelines to the users and/or guardians about potential adverse reactions to vaccines from $48.3 \%$ to $100 \%$, after 8 months of Phase I. Therefore, the changes tested resulted in an improvement that was considered sustainable (Figure 4). 


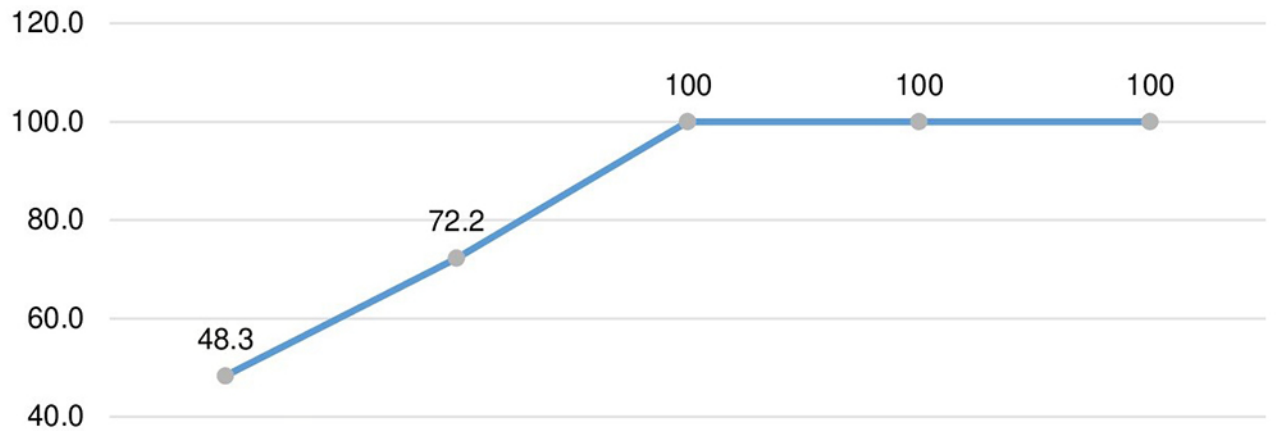

40.0

20.0

.0

Phase 1 (Baseline) $1^{\text {st }}$ PDSA cycle $2^{\text {nd }}$ PDSA cycle $3^{\text {rd }}$ PDSA cycle $4^{\text {th }}$ PDSA cycle

Figure 4 - Percentage of guidelines given to the users and/or guardians about vaccine-related adverse events in Phase 1 (baseline) and in the $1^{\text {st }}, 2^{\text {nd }}, 3^{\text {rd }}$ and $4^{\text {th }}$ PDSA Cycles. Araraquara, São Paulo, Brazil.

Although it was not the study objective, the method selected for this research also allowed the interventions tested during the PDSA cycles to influence the change in behavior of the Nursing team. For example, the team was aware of other flaws in the processes that could result in harms to the users, such as: maintenance of needles in vials after aspiration of doses and failure to perform skin asepsis before the injections.

The IHI quality improvement methodology, based on PDSA cycles, also contributed to the involvement of the medical team in making decisions about the changes to be tested.

\section{DISCUSSION}

A total of 164 doses of vaccines were observed and several errors in the processes of preparation and administration of medications were identified, the main ones being: not preparing the vaccine in a clean and dry place, not performing any technique for pain relief, and not observing adverse reactions. Immunization errors, in addition to having the potential to cause harms, can also result in a loss of bond with the service and trust on the part of the user, which can reflect in the reduction of vaccination coverage and consequent exposure to diseases which are preventable through the vaccine ${ }^{19}$.

Lack of training and/or qualification of the team on adverse events to the vaccine was one of the causes pointed out by the team during the analysis of the root cause of the factors that contributed to the low percentage of guidelines given to the users and/or guardians. The health team recognized the complexity of the topic and expressed a desire to expand their knowledge to improve the assistance provided to the population.

Permanent education is a fundamental strategy to promote the training and qualification of human resources for the Unified Health System (Sistema Único de Saúde, SUS), in order to improve the quality of the services provided to the users. In addition, permanent education reflects on the prevention and reduction of adverse events associated with health care, by raising awareness in the professionals ${ }^{20}$.

Currently, it is possible to use technical and technological resources as a tool to facilitate the construction of knowledge itself in the development and improvement of the professional practice ${ }^{21}$.

It is noteworthy that the Nursing team showed more confidence in carrying out the procedures related to the preparation and administration of vaccines after training, and also demonstrated greater involvement in the processes. 
In this study, four PDSA cycles were needed to evidence $100 \%$ improvement in guidelines provided to the users or guardians about adverse reactions after vaccination. In a retrospective survey conducted in Michigan, USA, with the objective of reducing the unsuitable use of intravenous antihypertensive drugs in $25 \%$ of the cases, three PDSA cycles were necessary and the following intervention was tested: educational actions directed at different groups to obtain favorable results. According to the researchers, there was a $52 \%$ increase in patient safety. As a secondary result, they obtained a reduction in costs related to intravenous drugs ${ }^{22}$.

In the $1^{\text {st }}$ PDSA cycle, approximately $27.8 \%$ of the users and/or guardians were not informed about the potential adverse reactions related to the vaccine. At this time, changes were recommended and included training the team on the topic; availability of a folder containing the types of vaccines and local and systemic reactions in the vaccination room; and a ban on the use of cell phones was also recommended in order to enable the user or guardian to receive the guidelines properly and without interruption. The target of $100 \%$ of guidelines was reached in the $2^{\text {nd }}$ and $3^{\text {rd }}$ cycles and was maintained after 30 days from the baseline ( $4^{\text {th }}$ PDSA cycle). Thus, the changes resulted in an improvement that was considered sustainable, as it has been maintained over time.

In addition to the Nursing team, it was identified that the medical team was also involved in making decisions about the changes to be tested. Such methodology allows for the construction of knowledge, in addition to improving the teams' knowledge about care processes. In a research study carried out by the author and collaborators, with the objective of implementing a quality improvement program to reduce errors in the preparation and administration of drugs via nasogastric or nasoenteric tubes, it was identified that the collaborative approach to quality improvement, based on PDSA cycles, can reduce the proportion of errors in the preparation and administration of medications ${ }^{23}$.

One of the limitations of this study was its relatively small sample size. The study was also carried out in a single BHU in the inland of São Paulo and the results may not reflect the reality of other services. The results of this improvement project were monitored for a brief period of time. Future long-term research studies are recommended to monitor other outcome measures. It is also suggested to reproduce the study on a larger scale and evaluate the impact of these interventions on other measures.

\section{CONCLUSION}

It took four PDSA cycles to reach the project's goal, which was to increase to $100 \%$ the guidelines given to the users and/or companions about the potential adverse events related to the administration of vaccines, over an eight-month period.

The results demonstrate that the quality improvement approach, based on PDSA cycles, contributed to the reduction of errors in the vaccine administration process, as there was an increase in the percentage of guidelines given to the users and/or guardians about potential adverse reactions to vaccines and that the change was sustainable, as it has been maintained over time.

\section{REFERENCES}

1. World Health Organization. The third WHO Global Patient Safety challenge: medication without harm. Zurique: WHO; 2017 [cited 2020 Feb 16]. Available from: https://www.who.int/patientsafety/ medication-safety/en/

2. Assiri GA, Shebl NA, Mahmoud MA, Aloudah N, Grant E, Alijadhey H, et al. What is the epidemiology of medication errors, error-related adverse events and risk factors for errors in adults managed in community care contexts? A systematic review of the international literature. BMJ Open [Internet]. 2018 [cited 2020 Mar 18];8(5):e019101. Available from: https://doi.org/10.1136/ bmjopen-2017-019101 
3. Auraaen AL, Slawomirski L, Klazinga N. The economics of patient safety in primary and ambulatory care: flying blind. OECD Health Working Papers [Internet]. 2018 [cited 2020 Apr 19]; 106. Available from: https://doi.org/10.1787/baf425ad-en

4. Khalil H, Kirschbaum M. Adverse Drug Reactions in Primary Care: A scoping review protocol. JBI Database System Rev Implement Rep [Internet]. 2018 [cited 2020 June 08];16(3):615-21. Available from: https://doi.org/10.11124/JBISRIR-2017-003471

5. Hoeve CE, Van Haren A, Sturkenboom MCJM, Straus SMJM. Spontaneous reports of vaccination errors in the European regulatory database EudraVigilance: a descriptive study. Vaccine [Internet]. 2018 [cited 2020 Mar 18];36(52):7956-64. Available from: https://doi.org/10.1016/j. vaccine.2018.11.003

6. Centers for Disease Control and Prevention. Understanding the vaccine adverse event reporting system (VAERS). Atlanta (US): Centers for Disease Control and Prevention, 2013.

7. Pacheco FC, Domingues CMAS, Maranhão AGK, Carvalho SMD, Teixeira MAS, Braz RM, et al. Análise do sistema de informação da vigilância de eventos adversos pós-vacinação no Brasil, 2014 a 2016. Rev Panam Salud Publica [Internet]. 2018 [cited 2020 Mar 18];42:e122018. Available from: https://doi.org/10.26633/RPSP.2018.12

8. Institute for Healthcare Improvemente (US). How to improve. Cambridge, MA (US): Institute for Healthcare Improvement; 2016 [cited 2019 Dec 19]. Available from: http://www.ihi.org/resources/ pages/howtolmprove/default.aspx

9. Eales S, Burdett TM, Birch G. Development and implementation of core competencies for integrated care community health teams: a UK experience. Int J Integr Care [Internet]. 2018 [cited 2020 Jan 29];18(Suppl 2):A322. Available from: https://doi.org/10.5334/ijic.s2322

10. Borg SJ, Crossland L, Risk J, Porritt J, Jackson CL. The primary care practice improvement tool (PC-PIT) process for organisational improvement in primary care: application by Australian primary health networks. Aust J Prim Health [Internet]. 2019 [cited 2019 Nov 23];25(2):185-91. Available from: https://doi.org/10.1071/PY18106.

11. Coury J, Schneider JL, Rivelli JS, Petrik AF, Seibel E, D'Agostini B, et al. Applying the Plan-DoStudy-Act (PDSA) approach to a large pragmatic study involving safety net clinics. BMC Health Serv Res [Internet]. 2017 [cited 2019 Nov 16];17(1):411. Available from: https://doi.org/10.1186/ s12913-017-2364-3

12. Langley GJ, Moen R, Nolan KM, Nolan TW, Norman CL, Provost LP. The improvement guide: A practical approach to enhancing organizational performance. San Francisco (US): Wiley; 2009.

13. Institute for Healthcare Improvemente (US). How to improve [Internet]. Boston (US): Institute for Healthcare Improvement; 2016 [cited 2019 Dec 19]. Available from: http://www.ihi.org/resources/ Pages/Howtolmprove/default.aspx

14. Agência Nacional de Vigilância Sanitária (BR). Serviços de atenção materna e neonatal: segurança e qualidade. Brasília, DF(BR): ANVISA; 2014.

15. Standards for Quality Improvement Reporting Excellence (US). SQUIRE. Promoting Excellence in Helthcare Improvement Reporting. 2017 [cited 2019 Mar 15] Available from: http://www.squirestatement.org/index.cfm?fuseaction=page. viewpage\&pageid=471

16. Ministério da Saúde (BR). Secretaria de Vigilância em Saúde. Departamento de Vigilância das Doenças Transmissíveis. Manual de Normas e Procedimentos para Vacinação. Brasília, DF(BR): Ministério da Saúde; 2014.

17. Taylor-Adams S, Vincent C. Systems analysis of clinical incidents: the London protocol. Clinical Risk. London (UK): Imperial College London; 2004. Available from: https://www.imperial.ac.uk/ patient-safety-translational-research-centre/education/training-materials-for-use-in-researchand-clinical-practice/the-london-protocol/ 
18. Institute for Healthcare Improvemente (US). PDSA Worksheet (short version). [cited 2019 Mar 15]. Boston (US): Institute for Healthcare Improvement; 2016. Available from: http://www.lhi.org/ education/ihiopenschool/resources/assets/pdsa_worksheet(short).Pdf

19. Bisetto LHL, Ciosak SI. Analysis of adverse events following immunization caused by immunization errors. Rev Bras Enferm [Internet]. 2017 [cited 2020 Mar 05];70(1):87-95. Available from: https:// doi.org/10.1590/0034-7167-2016-0034

20. Ternopolski CA, Baratieri T, Lenstck MH. Eventos adversos pós-vacinação: educação permanente para a equipe de enfermagem. Rev Esp Saúde [Internet]. 2015 [cited 2019 Mar 13];16(4):10919. Available from: http://168.194.69.20/index.php/espacosaude/article/view/388/13

21. Leal PM, Amante LN, Gironde JBR, Nascimento ERP, Magalhães ALP. Construindo soluções para segurança do paciente cardiopata em uso de varfarina: estudo qualitativo. Texto Contexto Enferm [Internet]. 2020 [cited 2020 June 13];29:e20180002. Available from: https://doi.org/10.1590/1980265X-TCE-2018-0002

22. Salman J, Salman A, Kumar S, Gjeka R, Tegeltija V, Peterson D, et al. Improving the use of intravenous antihypertensive medications in the hospital setting: a quality improvement initiative for patient safety. BMJ Open Qual [Internet]. 2019 [cited 2020 Feb 12];8(4):e000626. Available from: https://doi.org/10.1136/bmjoq-2019-000626

23. Pereira RA, Souza FB, Rigobello MCG, Pereira JR, Costa LRM, Gimenes FRE. Quality improvement programme reduces errors in oral medication preparation and administration through feeding tubes. BMJ Open Quality [Internet]. 2020 [cited 2020 Mar 30];9:e000882. Available from: https:// doi.org/10.1136/bmjoq-2019-000882 


\section{NOTES}

\section{ORIGIN OF THE ARTICLE}

Extracted from the dissertation - Impact of a quality improvement model in the reduction of errors related to the administration of vaccines in Basic Health Units, presented to the Professional MS Graduate Program in Nursing Technology and Innovation, of Escola de Enfermagem de Ribeirão Preto, Universidade de São Paulo, in 2020.

\section{CONTRIBUTION OF AUTHORITY}

Study design: Nunes MBM, Gimenes FRE.

Data collection: Nunes MBM.

Data analysis and interpretation: Nunes MBM, Teixeira TCA, Gabriel CS, Gimenes FRE. Discussion of the results: Nunes MBM, Gimenes FRE.

Writing and/or critical review of the content: Nunes MBM, Teixeira TCA, Gabriel CS, Gimenes FRE. Review and final approval of the final version: Nunes MBM, Teixeira TCA, Gabriel CS, Gimenes FRE.

\section{ACKNOWLEDGMENTS}

Araraquara City Hall and Daniela Cristina Maia Baptista.

\section{APPROVAL OF ETHICS COMMITTEE IN RESEARCH}

Approved by the Ethics Committee in Research with Human Beings of the Escola de Enfermagem de Ribeirão Preto, Universidade de São Paulo, under opinion No.3,076,215; Certificate of Presentation for Ethical Appreciation No. 98992918.4.0000.5393.

\section{CONFLICT OF INTERESTS}

There is no conflict of interests.

\section{EDITORS}

Associated Editors: Selma Regina de Andrade, Gisele Cristina Manfrini, Natália Gonçalves, Ana Izabel Jatobá de Souza.

Editor-in-chief: Roberta Costa.

\section{HISTORICAL}

Received: June 23, 2020.

Approved: December 08, 2020.

\section{CORRESPONDING AUTHOR}

Fernanda Raphael Escobar Gimenes

fregimenes@eerp.usp.br 